\title{
A Case of Ankyloblepharon-Ectodermal Defect-Cleft Lip and/or Palate (AEC) Syndrome with Missense Mutation in TP63 $1657^{\text {th }}$
}

Young Sun Kim, Tae Ho Hwang*, Su Jin Park, Hae Jung Lee, Sung Hoon Kim, Chul Hong Kim, Jun Hwa Lee, Ju Suk Lee, and Seoheui Choi*

Department of Pediatrics, Sungkyunkwan University School of Medicine, Samsung Changwon Hospital, Changwon, Korea Department of Pediatrics*, National Medical Center, Seoul, Korea

\section{ABSTRACT}

Ankyloblepharon-ectodermal defects-cleft lip and/or palate (AEC) syndrome, also known as Hay-Wells syndrome, is a rare autosomal dominant disorder characterized by congenital ectodermal dysplasia. It is caused by mutations in p63 gene. Six isoforms are generated from the TP63 gene mutation and the main isoform expressed in postnatal skin is Np63a, which functions as a key regulator of epidermal integrity. We have experienced a 1-day-old female baby with skin erosions, ankyloblepharosis, and cleft palate that require treatment for skin care and feeding difficulties. Missense mutation in TP63 $1657^{\text {th }} \mathrm{T} \rightarrow$ A transition was found in the genetic test performed in the patient, and this genotype has not been reported in a previously variant. The patient was found dead at 91days of birth and the cause of death was estimated by aspiration.

Key Words: Hay-Wells syndrome, Cleft palate, Ectodermal dysplasia

서론

Hay-Wells 증후군은 Ankyloblepharo-ectodermal defect-cleft lip and/or palate (AEC) 증후군 으로 불리우며, 1976년 Hay와 Wells에 의해 처음 보고되었다 ${ }^{1)}$. 이 질환은 외배엽의 형성장애 (Ectodermal dysplasia, ED)와 연관되어 구순열(Cleft lip) 또는 구개열(Cleft palate)과 함께 안검 유착(Ankyloblepharon)이 동반된다. 나타날 수 있는 동반 증상으로 치아 형성의 장애 및 출생 시 피부 박리와 피부 과각화증, 땀샘 형성 장애 및 그와 연관된 무한증 등의 증상이 동반될 수 있 다. 이환된 환자들은 신생아 시기에 안검유착에 대한 수술적 치료를 필요로 하며, 구순구개열 에 대한 수술적 교정 및 누관폐쇄증에 대한 검사가 필요하다. 중이염이 흔하게 발생하며, 땀샘 형성의 장애로 인하여 고체온증이 발생할 수 있으며, 지능은 정상이다. 질환의 원인으로는 p63 유전자 또는 3q27 염색에 위치에 있는 p53 유전자의 돌연변이에 의하여 발생하는 것으로 알려 져 있다 ${ }^{2)}$. 이 질환의 유병율은 매우 희귀하여 정확히 보고되어 있지 않으나 ${ }^{3)}$ 우리나라에서 2011
Received: 13 July 2017

Revised: 12 September 2017

Accepted: 23 September 2017

Correspondence to: Seoheui Choi

Department of Pediatrics, National

Medical Center, 245 Eulchiro, Jung-

gu, Seoul 04564, Korea

Tel: +82-2-2260-7306

Fax: +82-2-2260-7142

E-mail: taurus.choi@gmail.com

Copyright(c)

By Korean Society of Neonatology.

All right reserved.

This is an Open-Access article distributed under the terms of the Creative Commons Attribution Non-Commercial License (http://creativecommons.org/licenses/ by-nc/4.0), which permits unrestricted non-commercial use, distribution, and reproduction in any medium, provided the original work is properly cited. 
년 novel TP63 mutation에 의한 2례의 보고 ${ }^{4,5}$ 가 있었으며, 본 환 자는 기존에 알려지지 않은 유전자형의 과오 돌연변이(missense mutation)에 의해 발생하여 이에 보고하는 바이다.

\section{증례}

\section{환자: 이 $\mathrm{OO}$, 여아}

\section{주소: 수유 장애 및 다발성 표피 박리}

출생력 및 현병력: 환자는 재태연령 40주 5일, 출생 체중 3,210 g, 아프가 점수 1 분 7 점, 5 분 9점으로 질식 분만으로 출생하였다. 환자 는 출생 직후 구개열이 확인되었으며, 구순열은 없었다. 출생 후 피 부 자극, 물기 제거(dry up)를 시행하였을 때 얼굴, 두피, 등, 양하지,

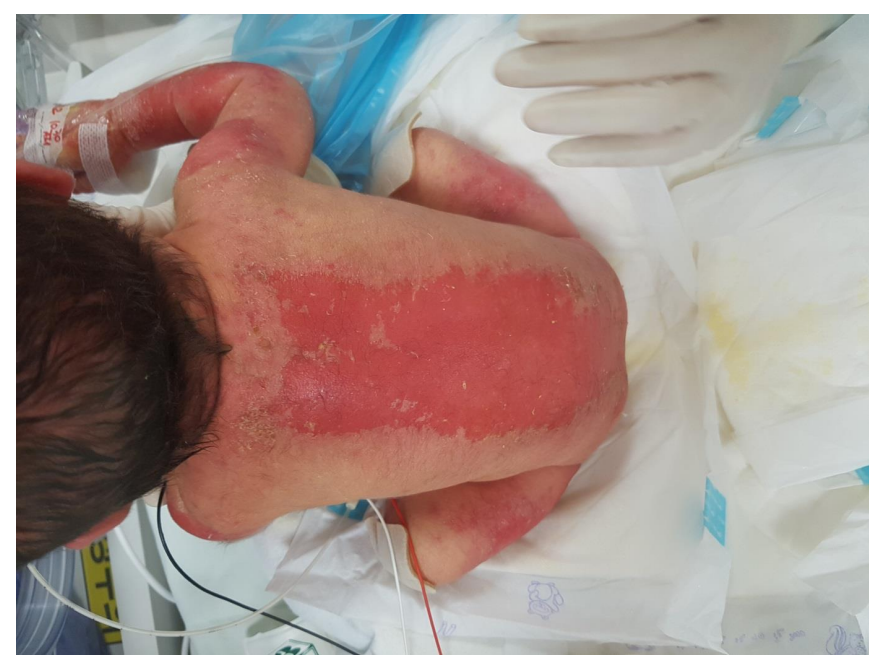

Figure 1. The excoriation on back was shown in the patient.

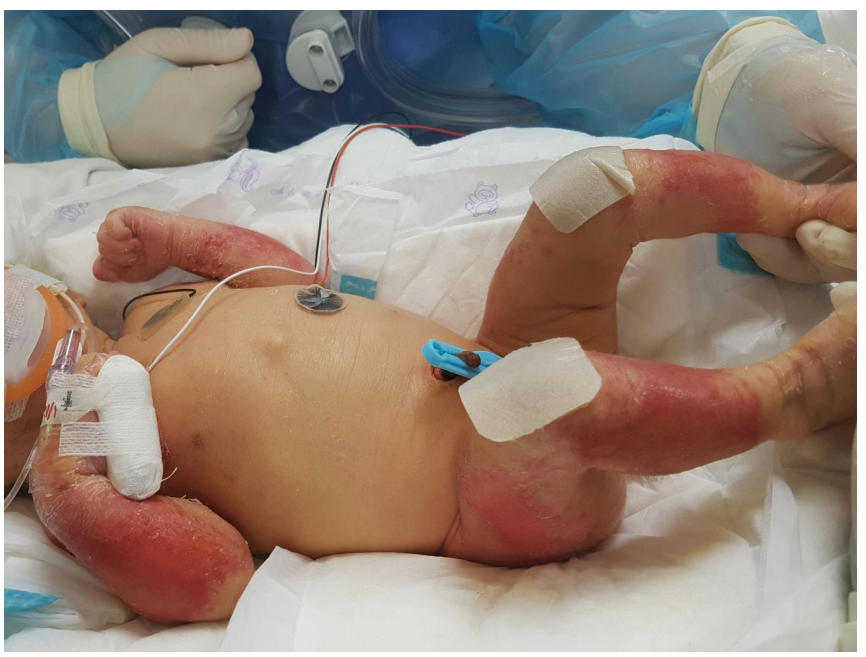

Figure 2. The excoriation on both upper and lower extremities was shown and mild arthrogryposis had found on elbow and knee joint in the patient.
양 손 등에 다발성 표피 박리가 발생하였으며 구개열로 인한 수유 진 행 장애 및 산소 포화도 저하가 발생하여 이에 대한 정밀 검사 및 치 료를 위해 출생 당일 삼성창원병원 신생아중환자실로 전원되었다.

산모력 및 가족력: 환자는 과거 1회의 임신 및 출산이 있었던 36세 산모로부터 두 아이 중 둘째로 출생하였으며, 임신기간 중 철분제, 엽산제, 갑상선 기능 저하증에 대한 신지로이드(synthyroid) 복용력 있었으며, 이외의 기타 기저 질환은 없었다. 환자를 포함하여 확인 한 3대까지의 직계 가족력 상 유산, 사산, 급사 및 유사한 모습을 가 진 가족은 없었다.

진찰 소견: 환자의 입실 당시 신장은 $51 \mathrm{~cm}(50-75 \mathrm{pp})$, 두위는 34 $\mathrm{cm}$ (75-90 pp), 체중은 3,120 g (25-50 pp) 으로 측정되었으며, 피부 병변(Figure 1) 이외 양측 상지 및 하지의 관절 구축(arthrogryposis, Figure 2), 구개열(Figure 3), 안검유착(Figure 4)이 확인되었다.

검사 소견: 입원 당시 시행한 검사상 일반 혈액 검사 백혈구 15,700 개 $/ \mu \mathrm{L}$, 혈색소 $18.9 \mathrm{~g} / \mathrm{dL}$, 혈소판 305,000 개/ $\mathrm{LL}$ 로 특이소견 없었다. 출생 30 일째 TP63 gene 에 대한 연구검사를 진행하였으며 출생 75일째 나온 유전자 검사 상 missense in TP63 $1657^{\text {th }} \mathrm{T} \rightarrow \mathrm{A}$ transition 으로 Leucine $\rightarrow$ Isoleucine 으로 변이된 기존 database 에 보고되지 않은 형태의 $\mathrm{AEC}$ 증후군으로 확인되었다(Figure 5).

치료 및 경과: 환자는 입원 직후 수유 시행 시 흡입이 잘 되지 않 고 수유 시 산소포화도 저하가 관찰되어 위관 수유 및 Harbermann'

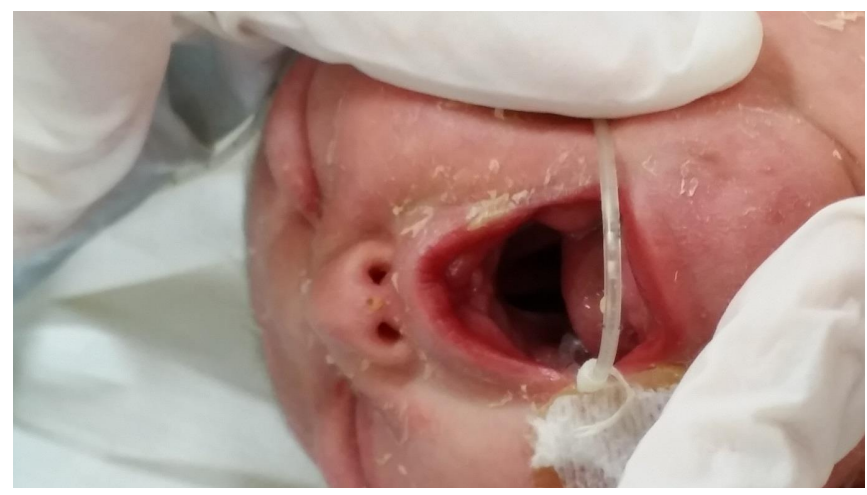

Figure 3. The cleft palate was found in her mouth.

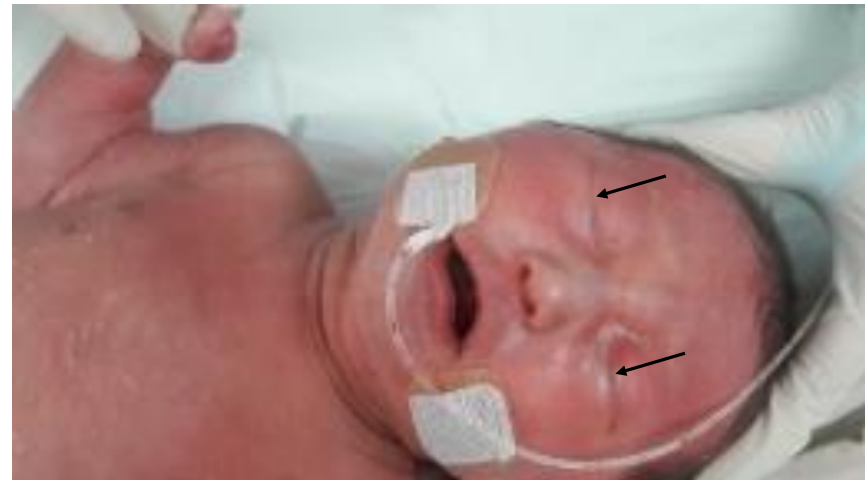

Figure 4. The ankyloblepharosis was found in the patient. 




Figure 5. Direct sequencing of the TP63 gene in the patient. A heterozygous missense mutation(NM_003722.4:c. 1657T>A(p.Leu553Ile)) was identified in the patient.

s feeder 를 이용한 경구 수유를 연습하였으며, 출생 3 일, 출생 23 일 째 안과 협진 하 bedside에서 국소적인 안검 분리 시술을 시행하였 다. 피부 병변에 대하여 항생물질 포함된 연고 도포 없이 보습 및 보 존적 치료를 시행하였다. 출생 7일째 화상양 병변의 호전 및 피부 discharge 호전되는 모습 보였으며, 양 하지의 병변만 남아 피부 관 리 및 수유에 대하여 보호자 교육하며 퇴원 준비하던 중 출생 8 일째 구강 점막의 백색 반점이 발생하고, 출생 9일째 발열 시작되어 혈액, 소변, 비강 및 피부 상재세균에 대한 배양 검사 시행하였으며, 검체 채취 후 Vancomycin과 3세대 cephalosporine 정맥 투여를 시작하였 다. 항생제 투약 시작 전 시행한 모든 검체에서 Methicillin-resistant Staphylococcus aureus (MRSA)가 동정되었다. 환자는 1주 간격으로 혈액배양검사를 시행하였으며, 항생제 투여전, 항생제 투여 7일째 혈액배양검사가 지속적으로 같은 균주가 확인되었다. 항생제 투여 14 일째 시행한 혈액배양검사가 최종적으로 음성임을 확인하여 19 일째 재배양을 시행하였으며, 19 일째 시행한 혈액배양검사 중간 보 고 음성을 확인한 후 항생제 치료를 종료하여 총 3주간 Vancomycin 투약을 시행하였다. 이후 보호자 수유 연습 및 피부 관리 교육 후 출 생 41 일째 소아성형외과, 소아정형외과, 소아재활의학과, 소아신경 과 추적 관찰 예정으로 모니터 대여하여 가정으로 퇴원하였다. 상기 환자 외래추적관찰 하던 중 출생 91일째 가정에서 분유 흡인에 의한 질식 추정으로 응급실 내원하였으며, 응급실 입실 당시 사망한 상태 로 확인되었다.

\section{고찰}

$\mathrm{AEC}$ 증후군은 외배엽 형성장애(ectodermal dysplasia, $\mathrm{ED}$ )의 일 종이며 외배엽에서 유래되는 조직들의 심각한 이상으로 발현된
다. 이 질환은 표피 발달의 핵심 부호화 조절인자(key regulators) 인 TP63 gene mutation으로 발생하며, 드문 단세대 유전질환 (monogenetic disorder)이다. $\mathrm{ED}$ 는 대략 200례 정도의 명확한 $\mathrm{ED}$ 형태가 보고되어 있으나 이 중 유전자 검사로 확인된 경우는 30\% 정도 밖에 밝혀지지 않았다 ${ }^{6,7)}$. TP63 gene의 mutation은 서로 다 른 $\mathrm{ED}$ 의 형태로 발현된다. 이러한 형태로는 Ectrodactyly, ectodermal dysplasia, and cleft lip/palate syndrome 3 (EEC 3; OMIM\# 604292), AcroDermato-Ungual-Lacrimal-Tooth syndrome (ADULT syndrome; OMIM\#103285), Limb-mammary syndrome (LMS; OMIM\#603543), Ankyloblepharon-ectodermal defets-cleft lip/ palate syndrome (AEC or Hay Wells syndrome; OMIM\#106260), Rapp-Hodgkin syndrome (RHS; OMIM\#129400), Split-Hand/Foot Malformation4 (SHFM4; OMIM 605289) 등으로 알려져 있으며 ${ }^{4,8}$, 이 는 AEC 증후군과 동일한 질환 범주에 포함되는 것으로 여겨지고, 피 부 침범 정도는 매우 다양하게 나타난달. 본 환자에서 임상 증상은 전형적인 안검유착이 발견되었으며, 눈썹 감소증, 손발톱 이상 및 구개열, 낮은 콧등의 특징적인 안면 소견 및 피부 병변을 보이고 있 었다. 이는 유전검사로 확인된 국내 2 번째 증례보고 환자에서 안검 유착의 임상 증상이 없었던 것 과 차이가 있었다.

TP63 gene의 mutation은 6개의 upregulation gene과 69개의 downregulation gene 의 상호작용으로 나타나며, 관여하는 gene 들은 epidermal adhesion과 skin barrier formation, 그리고 hair follicle 형성에 주된 영향을 미치는 gene들에 해당한다. 감소되는 유 전자형으로는 basement membrane proteins FRAS1, collagen VII, Skin barrier-associated small proline-rich proteins $1 \mathrm{~A}$ and 4 , late cornified envelope protein 5A, hornerin, lipid transporters including ALOX15B가 해당되며, hair-associated keratins 25, 27, 31, 33B, 34, 35,81 and 85 gene expression 도 감소한다. 유사한 변형이 두피와 
연관된 것으로 알려진 75 개의 gene 중 26 개에서 발현되었다고 보고 하고 있다 ${ }^{10)}$. 그러나, 유사한 증상임에도 불구하고 TP63 gene 이외 의 gene mutation 으로 증상 발생 시 유전자 검사상 진단에 어려움 을 겪을 수 있으며, 이에 대해 Exome analysis 를 이용하여 감별진 단을 한 보고도 있다 ${ }^{11)}$. 본 환자에서 임상 증상에 따른 유전학적 진 단을 위해 TP63 에 대한 직접염기서열분석을 연구검사로 의뢰하여 시행하였으며, 검사 결과 NM_003722. 4:c. 1657T>A(p.Leu553Ile) Heterozygous missense mutation 이 확인되었다. 이는 population database에 보고되지 않은 allele frequency를 가지고 있었으며, 이에 대해 HGMD의 disease causing mutation 보고와 Align-GVGD, SIFT, Polyphen-2 등의 In-Silico analysis를 시행한 바 일관적 deleterious mutation으로 예측되어 2015 ACMG/AMP guideline에 따라 likely pathogenic variant 로 확진 보고되었으며, 이에 따라 환자의 생물학 적 부, 모의 유전자 검사를 시행하려 하였으나 환자 사망 후 본원 추 적관찰이 지속되지 않았다.

환자는 입원한 기간 동안 이상 체온은 나타내지 않았으며, 피부 의 기저세포 형성 및 유지, 표피 분화 저하로 인한 피부 재생 장애로 인하여 피부 상재 세균으로 인한 혈액 배양검사 양성 패혈증으로 진 행되었다. 이는 국소 또는 전신 감염이 $\mathrm{AEC}$ 증후군의 가장 주된 사 망의 원인으로 알려진 것과 일치하며 ${ }^{12-14)}$, 본 환자는 넓은 피부 면적 의 광범위한 피부 장벽 손상으로 인한 것으로 추정하여 피부 상재 세 균인 그람 양성 균주에 대한 치료를 목표로 하였으며, 원내 7일 이상 재원 하였던 것을 근거로 항생제 내성 균주에 대한 가능성을 배재하 지 못하여 vancomycin을 추가하였으며, 배양 검사 상 methicillin 내 성 Staphylococcus aureus (MRSA)가 확인되어 상기 약제를 지속 유 지하였다. 이는 Morris와 Russell 등의 보고에 따르면 지역사회 획득 (Community acquired) Staphylococcus aureus 감염에서 $14.4 \%$, 원 내(Nosocomial infected) Staphylococcus aureus 감염에서 $46.6 \%$ 의 methicillin 내성 균주가 확인되는 바 ${ }^{15)}$ 피부 감염에 대한 1 차 선택 약 제의 선택에 신중을 기해야 할 것으로 판단된다. 피부 장벽 손상에 대하여 Mupirocin 연고 등이 사용되고 있으나 ${ }^{3)}$ Mupirocin 에 대한 내성 균주가 증가하고 있어 연고의 일반적인 사용보다는 선택적인 사용이 필요할 것으로 판단된다. Sheckter 등은 두피에 발생한 피부 병변에 대하여 acellular dermal matrix를 이용한 이식을 시도하였으 나 MRSA 감염에 의한 이식 후 합병증이 발생하였음을 보고하였으 며 ${ }^{16)}$, 감염에 대한 관리가 매우 어려워 아직까지 명확한 피부 관리의 지침이 확보되어 있지 않다 ${ }^{17)}$. 상기 질환은 유전 질환으로 주된 치 료는 증상 완화에 있으며 ${ }^{12)}$, 최근 다능성 줄기 세포(pluripotent stem cell)의 사용 ${ }^{8)}$ 도 치료로써 시도되고 있어 이에 대한 더 많은 연구가 필요하다.

신생아 시기에 확인된 유전질환은 환자 부모의 유전 검사 및 유전 상담이 동반되어야 하며 ${ }^{4)}$, 꾸준한 추적 관찰 및 시기별 적절한 중재 가 필요하다. Eisenkraft 등은 한 Ashkenazi-Jewish 가정에서 피부 발
현으로 발생한 4세 남아의 가계도 및 유전자 검사를 시행하여 TP63 유전자형의 이환을 확인하였다 ${ }^{18)}$. 따라서 이환된 환자는 직계 가족 및 이환 가능한 환자의 유전자형 검사가 필요할 수 있다. 본 환자는 부모 유전 검사를 포함한 유전 상담에 대하여 정서적 지지를 포함한 전인적인 접근이 필요하였고, 환자에 대한 적절한 교육이 지속적으 로 필요하였으나, 수유와 연관된 것으로 판단되는 질식에 의하여 가 정 내 사망하였다. 추후 같은 질환이 의심 또는 확진 될 경우 환자 및 보호자들의 교육 및 정서적, 경제적 지지가 매우 중요할 것으로 판단 된다. 저자들은 새로운 유전자형으로 확인된 $\mathrm{AEC}$ 증후군 1례를 진 단하였으며, 생후 91일 째 가정 내 사망하였기에 이에 보고하는 바 이다.

\section{감사의 글}

희귀 질환으로 유전자 검사 진행에 어려움을 겪고 있을 때 환자만 을 위해 TP63 유전자 검사를 진행해 주신 삼성서울병원 유전자센터 교수님들께 감사의 인사를 올립니다.

\section{REFERENCES}

1) Hay RJ, Wells RS. The syndrome of ankyloblepharon, ectodermal defects and cleft lip and palate: an autosomal dominant condition. Br J Dermatol 1976;94:277-89.

2) Jones KL. Hay-Wells syndrome. SMITH'S recognizable patterns of human malformation, 6th ed. Philadelphia: Elsevier, 2006: 332-3.

3) Nagaveni NB, Umashankara KV. Hay-Wells syndrome of ectodermal dysplasia: a rare autosomal dominant disorder. Indian J Hum Genet 2011;17:245-6.

4) Lee GH, Kwon MJ, Sung SI, Choi YB, Kim JK, Yoo HS, et al. AEC syndrome confirmed by genetic study in neonate: a case report. Korean J Perinatol 2011;22:367-71.

5) Song KH. Ankyloblepharon, ectodermal defects, and cleft lip and palate syndrome associated with TP63 gene mutation. Korean J Dermatol 2011;49:274-8.

6) Visinoni AF, Lisboa-Costa T, Pagnan NA, Chautard-Freire-Maia EA. Ectodermal dysplasias: clinical and molecular review. Am J Med Genet A 2009;149A:1980-2002.

7) Priolo M. Ectodermal dysplasias: an overview and update of clinical and molecular-functional mechanisms. Am J Med Genet A 2009;149A:2003-13.

8) Koch PJ, Dinella J, Fete M, Siegfried EC, Koster MI. Modeling AEC-New approaches to study rare genetic disorders. Am J Med Genet A 2014;164A:2443-54. 
9) Eisenkraft A, Pode-Shakked B, Goldstein N, Shpirer Z, van Bokhoven $\mathrm{H}$, Anikster Y. Clinical variability in a family with an ectodermal dysplasia syndrome and a nonsense mutation in the TP63 gene. Fetal Pediatr Pathol 2015;34:400-6.

10) Clements SE, Techanukul T, Lai-Cheong JE, Mee JB, South AP, Pourreyron C, et al. Mutations in AEC syndrome skin reveal a role for p63 in basement membrane adhesion, skin barrier integrity and hair follicle biology. Br J Dermatol 2012;167:13444.

11) Gripp KW, Ennis S, Napoli J. Exome analysis in clinical practice: expanding the phenotype of Bartsocas-Papas syndrome. Am J Med Genet A 2013;161A:1058-63.

12) Fete $M$, vanBokhoven $H$, Clements $S E$, McKeon $F$, Roop DR, Koster MI, et al. International Research Symposium on Ankyloblepharon-Ectodermal Defects-Cleft Lip/Palate (AEC) syndrome. Am J Med Genet A 2009;149A:1885-93.

13) Siegfried E, Bree A, Fete M, Sybert VP. Skin erosions and wound healing in ankyloblepharon-ectodermal defect-cleft lip and/or palate. Arch Dermatol 2005;141:1591-4.

14) Vanderhooft SL, Stephan MJ, Sybert VP. Severe skin erosions and scalp infections in AEC syndrome. Pediatr Dermatol 1993; 10:334-40.

15) Morris AK, Russell CD. Enhanced surveillance of Staphylococcus aureus bacteraemia to identify targets for infection prevention. J Hosp Infect 2016;93:169-74.

16) Sheckter C, Rommer E, Francis C, BlockV, Chen J, Rizvi M et al. Scalp erosion in Ankyloblepharon-Ectodermal Defect-Cleft Lip and/or Palate(AEC syndrome): treatment with acellular dermal matrix. J Craniofac Surg 2013;24:e28-30.

17) Guo S, Chen R, Xu Y, Mu Y, Chen L. Ankyloblepharon-Ectodermal Defects-Cleft Lip/Palate Syndrome. J Craniofac Surg 2017; 28:e349-51.

18) Eisenkraft A, Pode-Shakked B, Goldstein N, Shpirer Z, van Bokhoven $\mathrm{H}$, Anikster Y. Clinical variability in a family with an Ectodermal Dysplasia Syndrome and a nonsense mutation in the TP63 gene. Fetal Pediatr Pathol 2015;34:400-6. 